Pacific Northwest

National Laboratory

Operated by Battelle for the

U.S. Department of Energy

\section{Test Plan for Field Experiments to Support the Immobilized Low-Activity Waste Disposal Performance Assessment at the Hanford Site}

\author{
P. D. Meyer \\ B. P. McGrail \\ D. H. Bacon
}

September 2001

Prepared for the U.S. Department of Energy under Contract DE-AC06-76RL01830 


\section{DISCLAIMER}

This report was prepared as an account of work sponsored by an agency of the United States Government. Neither the United States Government nor any agency thereof, nor Battelle Memorial Institute, nor any of their employees, makes any warranty, express or implied, or assumes any legal liability or responsibility for the accuracy, completeness, or usefulness of any information, apparatus, product, or process disclosed, or represents that its use would not infringe privately owned rights. Reference herein to any specific commercial product, process, or service by trade name, trademark, manufacturer, or otherwise does not necessarily constitute or imply its endorsement, recommendation, or favoring by the United States Government or any agency thereof, or Battelle Memorial Institute. The views and opinions of authors expressed herein do not necessarily state or reflect those of the United States Government or any agency thereof.

PACIFIC NORTHWEST NATIONAL LABORATORY

operated by

BATTELLE

for the

UNITED STATES DEPARTMENT OF ENERGY

under Contract DE-AC06-76RLO1830 
PNNL- 13670

\section{Test Plan for Field Experiments to Support the Immobilized Low-Activity W aste D isposal Performance Assessment at the $\mathrm{H}$ anford Site}

P.D. Meyer

B.P. McGrail

D.H. Bacon

September 2001

Prepared for the U.S. Department of Energy

Under Contract DE-AC06-76RLO 1830

Pacific Northwest National Laboratory

Richland, Washington 99352 


\section{Summary}

Much of the data collected to support the Immobilized Low-Activity Waste Performance Assessment (ILAW PA) simulations have been obtained in the laboratory on a relatively small scale (less than $10 \mathrm{~cm}$ ). In addition, the PA simulations themselves are currently the only means available to integrate the chemical and hydrologic processes involved in the transport of contaminants from the disposal facility into the environment. This report describes the test plan for field experiments to provide data on the hydraulic, transport, and geochemical characteristics of the near-field materials on a more representative (i.e., larger) scale than the laboratory data currently available. The experiments will also provide results that encompass a variety of transport processes likely to occur within the actual disposal facility. These experiments will thus provide the first integrated data on the ILAW facility performance and will provide a crucial dataset to evaluate the simulation-based estimates of overall facility performance used in the PA.

The experiments will place cylinders of simulated glass waste in a sand backfill matrix within the existing Field Lysimeter Test Facility (FLTF) at the Hanford Site. The experimental cylinders will be $46 \mathrm{~cm}$ high and $20 \mathrm{~cm}$ in diameter and composed of two glass materials: a glass formulation that corrodes relatively quickly (HAN-28F) and a durable glass formulation more representative of the actual ILAW glass product (LAWA44). Nonradioactive tracers will be included in the glass formulations. The lysimeters will be irrigated to produce observable corrosion of the glass and measurable contaminant transport over the time span of the experiment. Tracer concentrations will be measured in samples collected from the lysimeter drainage using a passive capillary wick drainage system. The bottom of each lysimeter will be segmented to allow drainage water to be collected from a limited portion of the lysimeter area. In addition to the drainage measurements, water content, soil matric potential, soil temperature, $\mathrm{pH}$, and electrical conductivity measurements will be made to monitor the conditions within the lysimeters.

Depending on the final cost for the production of the experimental glass, modification of one to three of the FLTF lysimeters will take place in FY02, including installation of sensors and samplers. Excavation of one of the lysimeters containing HAN-28F glass and analyses of the excavated samples will take place in FY06, before emplacement of actual ILAW glass in the first disposal facility trench. The remaining two lysimeters, one containing HAN-28F glass and one containing LAWA44 glass, will continue to be monitored to provide a long-term data record of glass behavior. A schedule for excavation of these lysimeters will be based on the data record. 


\section{Contents}

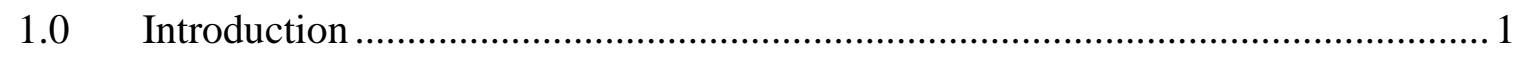

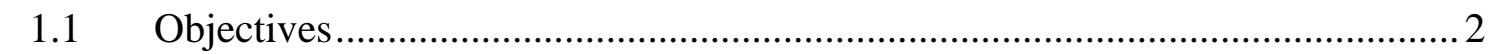

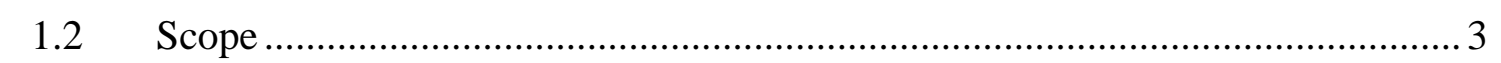

$2.0 \quad$ Experimental Design .............................................................................

$2.1 \quad$ Geometry and Glass Characteristics ............................................................

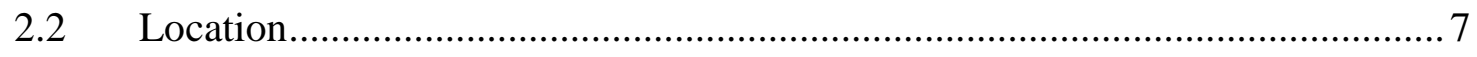

2.3 Irrigation Rate \& Backfill Properties ......................................................

3.0 $\quad$ Measurements and Analyses ........................................................................ 13

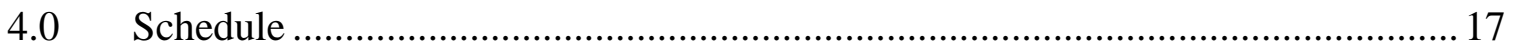

$5.0 \quad$ Environment, Safety, and Health .................................................................. 19

$6.0 \quad$ Waste and Residuals Management................................................................2

6.1 Management Activity A - Solid Waste Management Plan for FLTF Lysimeter

Modification ...................................................................................................... 21

6.2 Management Activity B - Solid Waste Management Plan for Operation of the

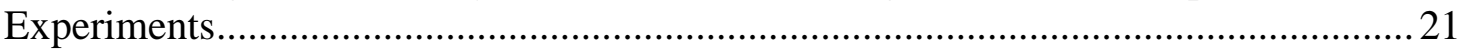

6.3 Management Activity C - Solid Waste Management Plan for Soil and Solution

Sampling........................................................................................................... 22

$7.0 \quad$ Quality Assurance ................................................................................23

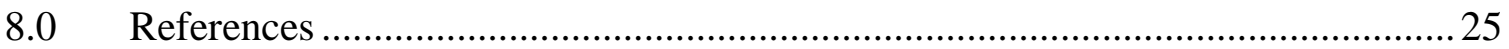




\section{Figures}

Figure 1. Plan View of Hexagonal Packing of Glass Cylinders in the Disposal Facility With a Representation of the Experimental Subunit.................................................. 31

Figure 2. Relative Size of Proposed Experimental Glass Blocks (Right) Compared to the Full-Size Blocks of the ILAW Disposal Facility (Left)..........................................32

Figure 3. Configuration of Experimental Glass Cylinders Within a Lysimeter................33

Figure 4. Plan View of the FLTF Showing the Current Experiments.............................34

Figure 5. Surface of FLTF (Left) Showing Several Lysimeters and a View from the Underground Vault (Right) showing the Side of a Lysimeter with Instrument Access Ports......................................................................................................... 35

Figure 6. Steady-State Volumetric Water Content for the Lysimeter Simulation with an Applied Water Flux Of $200 \mathrm{~mm} / \mathrm{yr}$ and the Fine (Top) and Coarse (Bottom) Backfill Properties........................................................................................................ 36

Figure 7. Simulated Rhenium Tracer Concentration in the Lysimeter Drainage for Three Applied Water Fluxes: Fine Backfill Properties (Top) and Coarse Backfill Properties (Bottom) ..................................................................................................... 37

Figure 8. Steady-State Pressure Head for the Lysimeter Simulation with the 50-cm (Top) and 20-cm (Bottom) Diameter Glass Cylinders Using an Applied Water Flux Of 200 $\mathrm{mm} / \mathrm{yr}$ and the Fine Backfill Properties............................................................... 38

Figure 9. Rhenium Concentrations After 10 Years of Dissolution with the 50-cm (Top) and 20-cm (Bottom) Diameter Glass Cylinders Using an Applied Water Flux of 200 $\mathrm{mm} / \mathrm{yr}$ and the Fine Backfill Properties.

Figure 10. Simulated Rhenium Tracer Concentration in the Lysimeter Drainage for the 50-cm (Large Can) and 20-cm (Small Can) Diameter Glass Cylinders Using an Applied Water Flux of $200 \mathrm{~mm} / \mathrm{yr}$ and the Fine Backfill Properties.......................4 40

Figure 11. Arrangement of the Passive Capillary Wick Collection Pans on the Bottom of the Lysimeters. Shaded Areas Indicate the Location of the Glass Cylinders Above the Collection Pans. The Table Provides the Radius of Pans, Areas Sampled, and Estimated Drainage in Each Pan ................................................................................. 41 


\section{Tables}

Table 1. Experimental Glass Formulations

Table 2. Hydraulic Parameters for Backfill Materials and Glass Used in the Simulations.. 9

Table 3. Long-term Average Drainage from Irrigated FLTF Lysimeters with Gravel or Sand at the Surface and Little or No Vegetation............................................................. 11

Table 4. Laboratory Measurements and Methods ......................................................... 15

Table 5. Field Measurements and Methods ................................................................ 15 


\subsection{Introduction}

The legacy of the earlier Hanford Site mission consists of approximately $204,000 \mathrm{~m}^{3}$ of radioactive and mixed waste stored in 177 buried single- and double-shell tanks in the Hanford Site 200 Areas. Some of the more important radionuclides in these wastes are ${ }^{3} \mathrm{H},{ }^{79} \mathrm{Se},{ }^{90} \mathrm{Sr},{ }^{99} \mathrm{Tc},{ }^{129} \mathrm{I},{ }^{126} \mathrm{Sn}$, and ${ }^{137} \mathrm{Cs}$, as well as isotopes and progeny of uranium, plutonium, neptunium, and americium. Disposal of this waste will involve retrieval of the waste from the tanks, separation of the waste into high-level and low-activity waste streams, and immobilization of each waste stream. Under the current plan, the waste will be immobilized by incorporating it within a glass matrix (a process called vitrification). The immobilized high-level waste will be stored on the Hanford Site until shipped to a federally approved repository. The immobilized low-activity waste (ILAW) will be disposed of in a near-surface burial facility in the 200 East Area of the Hanford Site.

Current plans for disposal of the ILAW call for the molten glass waste to be sealed in steel containers that will be placed in three layers within double-lined trenches. The design includes a leachate collection system between the liners and a protective surface barrier constructed over each trench at closure. The liner and surface barrier components will be similar to those used in the Hanford Radioactive Mixed Waste Disposal Facility. The ILAW Remote-Handled Trench is currently in the conceptual design stage as described in Burbank (2001) and Janin and Biyani (2000).

The goal of the ILAW Performance Assessment (PA) is to provide a reasonable expectation that the disposal of the waste protects the general public, groundwater resources, air resources, surface water resources, and inadvertent intruders. The radiological performance objectives to be used in the ILAW PA include dose limits for an all-pathways scenario and an inadvertent intruder scenario as well as concentration and dose limits in groundwater, surface water, and air (Mann and Puigh 2000). Performance objectives are evaluated for 1,000 and 10,000 years, but are calculated to the time of peak or 10,000 years, whichever is longer. Drinking water, residential farmer, and inadvertent intruder scenarios are considered in the ILAW PA (Mann and Puigh 2000). For the drinking water and residential farmer scenarios, the main pathway by which exposure occurs involves water movement into and through the disposal facility, dissolution of the waste, transport of contaminants through the unsaturated zone to the unconfined aquifer, transport in the aquifer to an extraction well, and human exposure via domestic use of the pumped water.

The 1998 ILAW PA (Mann et al. 1998) has been accepted by the U.S. Department of Energy. Additional simulations have been conducted to update the conclusions of the 1998 PA (Mann et al. 2000) based on more recently collected data (Mann and Puigh 2000). A draft of the 2001 ILAW PA (Mann et al. 2001) is currently in review. The ILAW PA project continues to collect a variety of information including geologic, geochemical, and hydraulic data from borehole samples, site-specific recharge data, 
geochemical information on contaminant transport through the site sediments, hydraulic and geochemical information for the expected materials of the disposal facilities, and data regarding the behavior of the expected waste form. Additional updates to the ILAW PA are planned as new information about the design and the characteristics of the disposal facility becomes available.

To date, much of the data collected to support the ILAW PA simulations have been obtained in the laboratory on a relatively small scale (less than $10 \mathrm{~cm}$ ). In addition, the PA simulations themselves are currently the only means available to integrate the chemical and hydrologic processes involved in the transport of contaminants from the facility into the environment. This report describes the test plan for field experiments to provide data to support the ILAW PA. These experiments will provide data on the hydraulic, transport, and geochemical characteristics of the near-field materials on a more representative (i.e., larger) scale than the laboratory data currently available. The experiments will also provide results that encompass a variety of transport processes likely to occur within the actual disposal facility. These experiments will thus provide the first integrated data on the ILAW facility performance and will provide a crucial dataset to evaluate the simulation-based estimates of overall facility performance used in the PA.

\subsection{Objectives}

The ILAW field experiments are intended to address specific issues related to flow and contaminant transport within the full-scale facility as well as provide a more comprehensive dataset of facility performance. As identified in the latest PA (Mann et al. 2001), the PA simulation results are sensitive to the glass dissolution assumptions, the recharge rate, the backfill hydraulic properties, and the diffusion coefficients. In addition, the representation of small-scale features within the disposal facility, such as the multiple layers of waste packages, had a significant impact on the facility's performance. Our knowledge of the spatial variability of flow and transport occurring within and around the glass waste, and the effect on glass dissolution and large-scale transport of this spatial variability, is among the most significantly uncertain components of the PA simulations. For these reasons, the ILAW field experiments described here address the near-field components of the full disposal facility. The near-field environment of the ILAW disposal facility consists of the materials within the disturbed region of the facility and includes the surface barrier components, the glass waste and surrounding backfill, and the liner materials.

Specific objectives of these experiments are to:

- Obtain a dataset that can be used to validate the models used in the near-field simulation of the ILAW PA. Ideally, the experimental data will demonstrate that the facility behaves as expected (i.e., as predicted using the current models) both in the near-term and in the distant future (i.e., as the glass corrodes). 
- Represent the important aspects of glass corrosion and the interaction of the glass corrosion products with the surrounding materials.

- Determine whether field-scale flow and transport are well represented by laboratory measurements of hydraulic and transport properties. If they are not, use data from the experiment to improve estimates of the effective material properties at the field scale.

- Provide data to validate models of the change in effective material properties over the life of the facility.

- Provide information on potential monitoring strategies for evaluating the nearfield performance of the full-scale facility.

- Reduce uncertainty in the ILAW PA predictions.

\subsection{Scope}

The ILAW PA simulations have demonstrated the complexity of the processes operating within the near-field of the disposal facility. The ultimate release of contaminants from the facility is a complex function of hydrology, geochemistry, and glass chemistry interacting with the design of the facility. Although the near-field includes the surface barrier and the trench liner, possible field-scale experiments conducted on these components as part of this study are not described here. Many of the scientific and engineering issues related to the surface barrier have been addressed by the prototype Hanford Barrier (DOE/RL 1999). Several additional issues related to the performance of the Modified RCRA C barrier slated for use at the ILAW disposal facility are being addressed by the recharge task of the ILAW PA project. The liner proposed for the ILAW disposal facility is similar to that installed at the Hanford Radioactive Mixed Waste Disposal Facility and, as a result, the engineering issues and many issues related to the performance of the liner have already been addressed (e.g., WHC 1994; Larrick et al. 1995, Whitlock 1995). The current conceptual design of the ILAW disposal facility has a diversion layer component located beneath the Modified RCRA C surface barrier. The diversion layer uses the principles of capillarity to provide an additional barrier to water movement into the disposal facility. Construction and performance issues for this component of the facility have not been adequately addressed by other studies or projects. The diversion layer is not included in the experimental facility design, however. Like the surface barrier, the diversion layer's purpose is to control (limit) the flux of water reaching the glass waste. For the experimental facility, the input water flux will be controlled to suit the purposes of the experiment. Possible field-scale experimental work related to the surface barrier and/or the diversion layer will be deferred until the Tank Farm Vadose Zone Project work on interim barriers is further along in its RCRA Corrective Action Program. 
The experiments described here are intended to be as simple as possible while including those processes that have the greatest impact on facility performance and about which there is significant uncertainty. As a result, the experimental design emphasizes the glass waste and the surrounding materials. Detailed measurements of flow and transport will be made of simulated glass waste packages buried in lysimeters. Water will be applied to the surface of the lysimeters, and the hydraulic and transport conditions will be monitored over several years. All drainage water will be collected and sampled. Destructive sampling of the lysimeter materials will take place after significant corrosion of the glass has occurred. Detailed descriptions of the experimental design and the planned measurements are contained in the following sections. 


\subsection{Experimental Design}

\subsection{Geometry and Glass Characteristics}

The actual glass waste packages to be produced for the ILAW disposal facility will be 213-cm-high cylinders, $122 \mathrm{~cm}$ in diameter. The glass waste packages will be placed in the ILAW disposal facility using hexagonal packing as shown in Figure 1 The expected average gap between waste packages is approximately $10 \mathrm{~cm}$. Space between the waste packages will be filled with backfill materials composed of sieved excavation spoils. Waste packages will be placed in rows running the length of the disposal trench with up to 10 waste packages across each row (Burbank 2001). Several layers, each consisting of two or more rows of waste packages, will be required to fill a trench. Approximately $1 \mathrm{~m}$ of backfill material will be used to cover each layer.

The hexagonal packing produces two distinct regions within a layer of the glass cylinders: the central region formed by three adjacent cylinders and the region along the edge of the layer (or row). Because of differences in the hydraulic properties of the glass and the backfill materials, it is anticipated that more water will flow between the glass cylinders than through them. As a consequence, the water content in the region between the cylinders is expected to be higher than the water content outside the row(s) of waste packages. Results from Mann et al. (2000) suggest that the chemistry and transport will be different in these two regions. To represent both regions in the experimental facility, a minimum of three glass cylinders (arranged as an equilateral triangle as shown by the shaded cylinders in Figure 1 is required. The simulation results reported in Mann et al. (2000) also suggest that the multiple layers of waste packages will affect the chemistry and transport within the facility. To investigate these effects in this experiment, two layers of (three) glass cylinders are needed.

Because of the cost to produce and handle full-size glass cylinders, the field experiments will use smaller glass cylinders. The size of the experimental glass cylinders was originally proposed to be $50 \mathrm{~cm}$ high and $50 \mathrm{~cm}$ in diameter. Due to the high cost of these cylinders, a smaller sized alternative was considered: $46 \mathrm{~cm}$ high and $20 \mathrm{~cm}$ in diameter. The relative size of the full-size glass and the proposed experimental glass cylinders is shown in

Figure 2. The size of the experimental glass cylinders represents a compromise between the cost to produce the glass and the desire to represent the key aspects of the flow and transport characteristics of the full-scale facility.

The actual glass waste to be produced for the ILAW disposal facility will be contained in stainless steel cylinders with walls $3.4 \mathrm{~mm}$ thick. The steel corrosion rate assumed in the 2001 ILAW PA results in the steel being completely eroded away within 1000 years 
(Bacon and McGrail 2001). The experimental glass will be emplaced without a steel casing since the steel would prevent any glass corrosion over the period of the experiment. The absence of steel corrosion products is not anticipated to adversely effect the experimental results. Simulations conducted by Bacon and McGrail (2001) showed that the steel corrosion products had a negligible effect on the glass dissolution rate. Emplacing the experimental glass without a steel casing increases the cost of the glass, however, since the glass must be removed from the mold in which it is poured, potentially requiring special materials for the mold and special handling during emplacement.

The actual ILAW glass will not be annealed and thus some fracturing is expected to occur, particularly on the outer edges of the cylinder where cooling will be most rapid. The fracturing is expected to create a total porosity of a few percent and to increase the surface area of the glass by up to ten times. These characteristics will be recreated in the experimental glass to the extent that this is practical. This may involve annealing the experimental glass and artificially fracturing or cutting it to increase the surface area. The best glass production process will be determined in concert with the glass manufacturer.

The proposed configuration of glass cylinders for the ILAW near-field experiment is shown in Figure 3 Two layers of three 20 -cm-diameter glass cylinders are shown with a $30-\mathrm{cm}$ spacing between layers. The glass cylinders are located within a 3-m high lysimeter with a diameter of $2 \mathrm{~m}$. The annular space of the lysimeter, including the space between and around the glass cylinders, is filled with backfill material. The experiment will consist of three lysimeters. Two of the lysimeters will be built using a glass formulation that corrodes relatively quickly; this glass is designated HAN-28F. The third lysimeter will contain a durable glass formulation more representative of the actual ILAW glass product; a modified form of the glass designated LAWABP1 (or an equivalent glass such as LAWA44) will be used. Proposed glass formulations are listed in Table 1. Nonradioactive tracers (iodine and oxides of rhenium, molybdenum, and selenium) will be included in the glass formulations. Rhenium, a surrogate for technetium, may be included at a lower concentration than the other tracers due to its high cost. 
Table 1. Experimental Glass Formulations

\begin{tabular}{|c|c|c|c|c|c|}
\hline \multicolumn{2}{|c|}{ HAN-28F } & \multicolumn{2}{|c|}{ LAWAB P1 (modified) } & \multicolumn{2}{|c|}{ LAWA44 (modified) } \\
\hline Oxide & wt \% & Oxide & wt $\%$ & Oxide & wt\% \\
\hline $\mathrm{Al}_{2} \mathrm{O}_{3}$ & $10.150 \%$ & $\mathrm{Al}_{2} \mathrm{O}_{3}$ & $10.000 \%$ & $\mathrm{Al}_{2} \mathrm{O}_{3}$ & $6.200 \%$ \\
\hline $\mathrm{B}_{2} \mathrm{O}_{3}$ & $2.000 \%$ & $\mathrm{~B}_{2} \mathrm{O}_{3}$ & $9.250 \%$ & $\mathrm{~B}_{2} \mathrm{O}_{3}$ & $8.900 \%$ \\
\hline $\mathrm{CaO}$ & $2.590 \%$ & $\mathrm{Cl}$ & $0.580 \%$ & $\mathrm{CaO}$ & $1.990 \%$ \\
\hline $\mathrm{Cl}$ & $0.130 \%$ & $\mathrm{Cr}_{2} \mathrm{O}_{3}$ & $0.020 \%$ & $\mathrm{Cl}$ & $0.650 \%$ \\
\hline $\mathrm{Cr}_{2} \mathrm{O}_{3}$ & $0.080 \%$ & $\mathrm{~F}$ & $0.040 \%$ & $\mathrm{Cr}_{2} \mathrm{O}_{3}$ & $0.020 \%$ \\
\hline$F$ & $0.310 \%$ & $\mathrm{Fe}_{2} \mathrm{O}_{3}$ & $2.500 \%$ & $\mathrm{~F}$ & $0.010 \%$ \\
\hline $\mathrm{Fe}_{2} \mathrm{O}_{3}$ & $2.530 \%$ & $\mathrm{~K}_{2} \mathrm{O}$ & $2.200 \%$ & $\mathrm{Fe}_{2} \mathrm{O}_{3}$ & $6.980 \%$ \\
\hline $\mathrm{K}_{2} \mathrm{O}$ & $1.960 \%$ & $\mathrm{La}_{2} \mathrm{O}_{3}$ & $2.000 \%$ & $\mathrm{~K}_{2} \mathrm{O}$ & $0.500 \%$ \\
\hline $\mathrm{MgO}$ & $1.180 \%$ & $\mathrm{MgO}$ & $1.000 \%$ & $\mathrm{MgO}$ & $1.990 \%$ \\
\hline $\mathrm{Na}_{2} \mathrm{O}$ & $28.620 \%$ & $\mathrm{Na}_{2} \mathrm{O}$ & $20.000 \%$ & $\mathrm{Na}_{2} \mathrm{O}$ & $20.000 \%$ \\
\hline $\mathrm{P}_{2} \mathrm{O}_{5}$ & $1.900 \%$ & $\mathrm{P}_{2} \mathrm{O}_{5}$ & $0.080 \%$ & $\mathrm{P}_{2} \mathrm{O}_{5}$ & $0.030 \%$ \\
\hline $\mathrm{SO}_{3}$ & $0.300 \%$ & $\mathrm{SO}_{3}$ & $0.100 \%$ & $\mathrm{SO}_{3}$ & $0.100 \%$ \\
\hline $\mathrm{SiO}_{2}$ & $42.560 \%$ & $\mathrm{SiO}_{2}$ & $41.580 \%$ & $\mathrm{SiO}_{2}$ & $44.280 \%$ \\
\hline $\mathrm{TiO}_{2}$ & $0.380 \%$ & $\mathrm{TiO}_{2}$ & $2.490 \%$ & $\mathrm{TiO}_{2}$ & $1.990 \%$ \\
\hline $\mathrm{ZrO}_{2}$ & $5.000 \%$ & $\mathrm{ZnO}$ & $2.600 \%$ & $\mathrm{ZnO}$ & $2.960 \%$ \\
\hline $\mathrm{ReO}_{2}$ & $0.010 \%$ & $\mathrm{ZrO}_{2}$ & $5.250 \%$ & $\mathrm{ZrO}_{2}$ & $2.990 \%$ \\
\hline $\mathrm{MoO}_{3}$ & $0.100 \%$ & $\mathrm{ReO}_{2}$ & $0.010 \%$ & $\mathrm{ReO}_{7}$ & $0.010 \%$ \\
\hline I & $0.100 \%$ & $\mathrm{MoO}_{3}$ & $0.100 \%$ & $\mathrm{MoO}_{3}$ & $0.100 \%$ \\
\hline \multirow[t]{2}{*}{$\mathrm{SeO}_{2}$} & $0.100 \%$ & I & $0.100 \%$ & I & $0.100 \%$ \\
\hline & & $\mathrm{SeO}_{2}$ & $0.100 \%$ & $\mathrm{SeO}_{2}$ & $0.100 \%$ \\
\hline
\end{tabular}

The lysimeters will be irrigated and instrumented to observe the spatial variability of the tracer transport and associated chemical changes. Conditions in the lysimeters containing the HAN-28F glass will be maintained to produce observable corrosion of the glass and measurable contaminant transport over the time span of the experiment. The lysimeter containing the modified LAWABP1 glass (or equivalent) will serve as a control and a demonstration of the expected glass performance. Although the lysimeter containing the modified LAWABP1 glass will have sufficient instrumentation to measure flow conditions and any potential transport, it is anticipated that this lysimeter will be less heavily instrumented than the others since minimal glass corrosion is expected.

\subsection{Location}

Three locations were considered for the lysimeters described above. One option was to construct the lysimeters and conduct the experiments inside a building. This option would allow for excellent access to the lysimeters for monitoring purposes and potentially good control over the environmental conditions. This option would require additional effort and cost to replicate field conditions, however. In addition, it does not make use of any existing infrastructure and would incur costs for the building space. 
A second option considered for the location of the lysimeters was on the south end of the ILAW disposal site, near the first ILAW borehole. The lysimeters would be installed within a subsurface vault that allowed access to the sides and bottoms of the lysimeters with the upper surface at ground level. Although proximity to the actual disposal facility makes the ILAW disposal site the preferred location, this option would require construction of the entire infrastructure for the facility.

The third and chosen option was to conduct the experiments in existing lysimeters at the Field Lysimeter Test Facility (FLTF), located between the 200 East and West Areas. The FLTF consists of 14 non-weighing lysimeters (2-m diameter by 3-m deep) and four weighing lysimeters installed within a subsurface concrete vault. Power and water are available at the site. Use of the existing FLTF infrastructure will reduce the overall cost of the experiments while satisfying the scientific requirements of the study. A plan view of the FLTF and the current experiments being conducted in the lysimeters are shown in Figure 4 . A number of the experiments are being conducted in support of the ILAW PA. Figure 5 shows the surface of the FLTF and a view from the subsurface vault showing the side of one of the lysimeters. Instrument access ports and installed tensiometers are visible. Working with interested parties, it was agreed that the lysimeters designated D10, D11, and D14 could be modified for these experiments with the least impact on longterm data records supporting other projects.

\subsection{Irrigation Rate and Backfill Properties}

One of the primary experimental parameters controlling the transport in the lysimeters is the applied water. The applied water flux for this experiment must be large enough to ensure that sufficient glass corrosion and tracer transport occurs within the time period of the experiment but not so large that tracer concentrations are diluted beyond measurement capabilities. Simulations of the experiment were conducted to evaluate the effect of the irrigation rate on the transport of the rhenium tracer from the glass. Three steady-state irrigation rates of 50,200, and $500 \mathrm{~mm} / \mathrm{yr}$ were simulated.

For these simulations, two sets of backfill hydraulic properties were used based on measurements conducted on samples from a borehole near the southwest corner of the ILAW site and from the excavation for the (former) Grout Vault site east of the PUREX facility 1 . The borehole samples (fine backfill) are expected to be similar to the excavation spoils from the construction of the ILAW trenches. The Grout Vault samples (coarse backfill) are coarser materials included in the simulations to evaluate the effect of the backfill properties on tracer transport. The hydraulic parameters used in the simulations

\footnotetext{
${ }^{1}$ Lenhard R. J. and P. D. Meyer, Hydraulic and Diffusion Property Measurements of ILAW Near-Field Materials: FY00 Status Report, Letter Report to CH2MHill Hanford Group Inc., Pacific Northwest National Laboratory, November 3, 2000.
} 
are given in Table 2. The glass hydraulic parameters were taken from Meyer and Serne (1999).

Table 2. Hydraulic Parameters for Backfill Materials and Glass Used in the Simulations

\begin{tabular}{llll}
\hline Hydraulic Parameter & Fine Backfill & Coarse Backfill & Glass \\
\hline Residual water content & 0.086 & 0.012 & 0.0 \\
Saturated water content & 0.392 & 0.393 & 0.02 \\
van Genuchten's $\alpha, \mathrm{cm}^{-1}$ & 0.0193 & 0.10 & 0.2 \\
van Genuchten's n & 3.22 & 3.91 & 3.0 \\
Ksat, cm/s & $6.6 \times 10^{-4}$ & $3.4 \times 10^{-3}$ & 0.01 \\
\hline
\end{tabular}

Two-dimensional simulations of glass corrosion and transport were carried out on a cross section through two HAN-28F glass cylinders. No ion exchange rate was assumed because not enough laboratory data are yet available for this glass. The HAN-28F forward dissolution rate constant was assumed to be five times greater than that of HLP31 (McGrail et al. 2001). Laboratory experiments currently underway will provide better estimates of the reaction rates for the HAN-28F glass. Glass dissolution was assumed to be limited by equilibrium with aqueous Si concentrations, with an assumed equilibrium coefficient equal to that of amorphous silica from the EQ3/6 database (Wolery 1992).

The steady-state volumetric water contents for the two sets of backfill properties and an applied water flux of $200 \mathrm{~mm} / \mathrm{yr}$ are shown in

Figure 6. which illustrates the location of the $50-\mathrm{cm}$ by $50-\mathrm{cm}$ glass cylinders that appear as the square low-water content zones. The simulated steady-state water content in the fine backfill is higher than that in the coarse backfill. As a result of the interaction between the hydraulic properties of the backfill and the glass, however, the water content in the glass is higher when the coarse backfill is used. The flow lines demonstrate that the water tends to flow around the glass with the fine backfill. Since the glass hydraulic parameters are relatively uncertain, this result may not represent the behavior of the actual experiment. It is hoped that the results from the two sets of backfill properties bound the potential behavior of the experiment and that conclusions based on these results will therefore still be valid.

Simulated rhenium tracer concentrations in the drainage from the lysimeter are shown in Figure 7. Results are presented for the three applied water fluxes and for the two sets of backfill properties. As the applied water flux decreases, the steady-state rhenium concentration increases and the time to reach the steady-state value increases. Steadystate concentration is reached in 2 years or less for water fluxes greater than $200 \mathrm{~mm} / \mathrm{yr}$. 
The coarse backfill properties result in higher steady-state rhenium concentrations and a shorter period of time to reach the steady-state values. As discussed above, this result occurs because the interaction between the backfill and glass hydraulic properties produces much larger water contents in the glass when the coarse backfill properties are used.

The natural background concentration of rhenium is expected to be at or near the detection limit, which is on the order of 1 to $5 \mathrm{ppm}$. This is equivalent to a rhenium concentration of $5 \times 10^{-9}$ to $3 \times 10^{-8} \mathrm{~mol} / \mathrm{kg}$ (the concentration units plotted in Figure 7 ). The simulation results suggest that the applied water flux should be no greater than 200 $\mathrm{mm} / \mathrm{yr}$ with the fine backfill properties. Applying a larger flux may lead to rhenium concentrations that are undetectable or indistinguishable from background levels. With the coarse backfill properties, rhenium concentrations are predicted to be large enough to allow greater leeway in the applied water flux. Because of uncertainty in the hydraulic properties of the glass, however, $200 \mathrm{~mm} / \mathrm{yr}$ may be a prudent upper limit for this case as well.

Simulations were also carried out to examine the impact on flow and transport of using the smaller (20-cm diameter) experimental glass cylinders. Simulations of the smaller cylinders were carried out using the fine backfill hydraulic properties and an applied water flux of $200 \mathrm{~mm} / \mathrm{yr}$. Figure 8 hhows the steady-state pressure head for the two experimental cylinder sizes. The range of pressures is similar, although the larger cylinders create a correspondingly larger region of low pressure beneath the glass. Figure G depicts the rhenium concentration in space after 10 years of glass dissolution. The smaller cylinders affect a smaller area, but the concentrations are only slightly lower than for the larger cylinders. Figure 10 is a plot of rhenium concentration in the lysimeter drainage as a function of time. The results suggest that the smaller glass cylinders will produce sufficiently high concentrations to be measurable in the drainage.

The two-dimensional simulation results presented above are a distortion of the threedimensional flow and transport. In particular, using the smaller glass cylinders is likely to result in a greater reduction in the drainage concentration than Figure 10 indicates. This is because the relative volume and surface area of the two cylinder sizes is greater than the relative cross-sectional area used in the simulations. The reduction in tracer concentration from using smaller cylinders can by compensated in two ways. First, the lower volume of material means that the rhenium concentration can be increased without a dramatic increase in glass materials costs. Second, lysimeter drainage can be collected using a segmented collection pan, reducing the dilution of the tracers from the larger volume of tracer-free water. Such a collection scheme is described in the following section.

The lysimeters in which the experiments will take place are on the irrigated side of the FLTF. In addition to the natural precipitation that falls on these lysimeters, an overhead irrigation system mounted on a track is used to apply untreated Columbia River water to meet a monthly total applied water target of three times the average natural precipitation for each month. Irrigation water is typically applied at a rate of $4 \mathrm{~mm} / \mathrm{hr}$ in increments 
ranging from 3 to $35 \mathrm{~mm}$ per application (Fayer et al. 1999). There are several lysimeters with long-term drainage records that can be used to estimate the expected water flux if the FLTF irrigation system is used in these experiments with no modification. These lysimeters all have sand or gravel at the surface with little or no vegetation. Two of the lysimeters are the small, clear-tube lysimeters, designated C4 and C5 in Figure 4.

Average yearly drainage rates are given in Table 3 for six FLTF lysimeters with applicable data records of 2 - 11 years. Drainage for the lysimeters with sand at the surface ranged from 62 to $174 \mathrm{~mm} / \mathrm{yr}$. With gravel at the surface, drainage was over 300 $\mathrm{mm} / \mathrm{yr}$. These data suggest that with a sand backfill and no vegetation at the soil surface it should be possible to achieve an average yearly drainage flux of 100-200 mm/yr using the existing FLTF irrigation system under its historical application schedule. The actual application rate and the hydraulic conditions within the lysimeters will be monitored. Surface soils can potentially be modified to increase or decrease the average drainage flux as needed.

Table 3. Long-Term Average Drainage from Irrigated FLTF Lysimeters with Gravel or Sand at the Surface and Little or No Vegetation.

\begin{tabular}{llll}
\hline No. & Description & Data Record & Drainage $(\mathbf{m m} / \mathbf{y r})$ \\
\hline D12 & Hanford Barrier w/ Dune Sand & $11 / 19 / 97-11 / 19 / 00$ & 132.6 \\
W4 & Hanford Barrier w/ Dune Sand & $11 / 19 / 97-11 / 19 / 00$ & 62.2 \\
D8 & Dune Sand & $11 / 24 / 98-11 / 24 / 00$ & 174.0 \\
D11 & Sandy Gravel & $1 / 4 / 95-12 / 31 / 00$ & 357.0 \\
C4 & Rounded Gravel Mulch Over Sand & $2 / 8 / 90-2 / 6 / 01$ & 330.8 \\
C5 & Pitrun Sand & $2 / 8 / 90-2 / 6 / 01$ & 63.3 \\
\hline
\end{tabular}




\subsection{Measurements and Analyses}

In situ measurements to characterize flow and transport within the lysimeters will be made over the course of the experiment to monitor the hydraulic conditions and the progress of the glass dissolution and tracer transport. In addition, destructive sampling will be carried out at the end of the experiment to provide data on the spatial variability of the tracers and to allow direct examination of the corroded glass.

Because the applied water flux will vary in time, hydraulic conditions within the lysimeters will also vary. These conditions will be monitored to provide the data necessary to model glass corrosion and transport. Water content and soil matric potential measurements will be made in the backfill materials. The simulations described above suggest that volumetric water contents in the range of 0.04 to 0.20 and soil water pressures in the range of -20 to $-200 \mathrm{~cm}$ could be expected under a steady application of water. Excursions outside these ranges in response to a variable water flux are expected, and the instrumentation will be chosen appropriately. Soil matric potential will be monitored with a combination of porous cup tensiometer measurements and heat dissipation sensors. The heat dissipation sensors are better for automated measurements and can measure in dryer conditions. The tensiometers are appropriate for measuring soil water potential under very moist conditions. Capacitance probes will be used to measure water content. Measurements of matric potential and water content will be made at three depths within each lysimeter. Soil temperature will be measured at two depths, above and below the glass cylinders.

At least three laboratory cores of the backfill material will be prepared and packed at the approximate bulk density achieved in the lysimeters. Water retention, saturated hydraulic conductivity, and at least one steady-state unsaturated hydraulic conductivity measurement will be made on these samples. Particle density and particle size distribution will also be measured on samples of the backfill material.

Chemical conditions will be measured using $\mathrm{pH}$ and electrical conductivity probes with changes over time used to monitor glass corrosion. Extraction of soil water using suction samplers was considered but rejected. These samplers disturb the flow field by their size and by their action in extracting soil water using suction. Tracer concentrations will be measured in samples collected from the lysimeter drainage using a passive capillary wick drainage system. This type of drainage collection system is currently used at the FLTF. Nylon wicks will be used to minimize contamination of the effluent. The bottom of each lysimeter will be segmented to allow collection of drainage water from a limited portion of the lysimeter area. The proposed configuration is shown in Figure 11, where four segments are defined by concentric circles. Each segment will be drained via its own wick allowing the measurement of tracer concentrations not only in time but also in (a limited) space. Glass tracer concentrations will be measured using Inductively Coupled Plasma Mass Spectrometry (ICP-MS) or ICP Optical Emission Spectrometry (ICP-OES). 
In addition to the tracers in the glass, tracer(s) will be applied at the surface of the lysimeters and transported with the irrigation water. The tracers applied with the irrigation water will be used to provide additional information on the hydrogeologic properties of the backfill/glass materials, especially the pore volume, porosity, conductivity, dispersion/diffusion characteristics, potential solute transport through the glass, and the changes in flow caused by the glass cylinders. A concentrated solution (pulse) of the selected tracer(s) (KBr, Penta-fluoro benzoic acid, and/or Ethanol) will be applied to the top few $\mathrm{cm}$ of the lysimeter soil. The tracer solution will mix with the irrigation water flux at the surface. Tracer measurements will be made on the solution samples collected at the base of the lysimeters. Ultraviolet (UV) visible tracer analysis, which is very economical for tracer sample analysis, will be used if there is no significant UV interference from the background soil solution. If this is impossible due to interference, other methods will be used for tracer analysis.

At the completion of the experiments, the caissons/lysimeters and columns will be excavated to obtain samples that can be analyzed in the laboratory. Hydraulic properties and soil water tracer concentrations will be measured in excavated samples. In addition, $\mathrm{x}$-ray diffraction (XRD) and scanning electron micrograph (SEM) measurements will be made to determine chemical and structural changes in the glass and backfill materials resulting from the corrosion of the glass waste.

A summary of the measurements, methods, and procedures or references to be used in these experiments is presented in Table 4 (laboratory measurements) and Table 5 (field measurements). 
Table 4. Laboratory Measurements and Methods

\begin{tabular}{|c|c|c|}
\hline Measurement & Method & Procedure/Reference \\
\hline Particle Density & Pyncnometer & $\begin{array}{l}\text { PNL-MA-567-SA-9, Blake and Hartge } \\
\text { (1986b) }\end{array}$ \\
\hline $\begin{array}{l}\text { Particle Size } \\
\text { Distribution }\end{array}$ & Sieve and Hydrometer & $\begin{array}{l}\text { PNL-MA-567-SA-2 \& 3, ASTM D } \\
\text { 422-63, Gee and Bauder (1986) }\end{array}$ \\
\hline Dry Bulk Density & Core Mass/Volume & $\begin{array}{l}\text { PNL-MA-567-SA-8, Blake and Hartge } \\
\text { (1986a) }\end{array}$ \\
\hline Water Retention & $\begin{array}{l}\text { Pressure Plate and } \\
\text { Vapor Adsorption }\end{array}$ & PNL-MA-567-SA-6, Klute (1986) \\
\hline $\begin{array}{l}\text { Saturated Hydraulic } \\
\text { Conductivity }\end{array}$ & Constant Head & $\begin{array}{l}\text { PNL-MA-567-SA-4, Klute and } \\
\text { Dirksen (1986) }\end{array}$ \\
\hline $\begin{array}{l}\text { Unsaturated Hydraulic } \\
\text { Conductivity }\end{array}$ & Steady-State Flux & Klute and Dirksen (1986) \\
\hline $\begin{array}{l}\text { Mo, Re, Se Tracer } \\
\text { Concentration }\end{array}$ & ICP-MS & PNNL-AGG-415, Rev. 0 \\
\hline I Tracer Concentration & ICP-OES & PNNL-AGG-ICP-AES, Rev. 0 \\
\hline $\begin{array}{l}\text { Surface Tracer } \\
\text { Concentration }\end{array}$ & UV Analysis & $\begin{array}{l}\text { Willard et al. (1988), Saripalli et al. } \\
\text { (1998) }\end{array}$ \\
\hline Glass Characteristics & XRD, SEM & RPL-XRD-PIP, Rev. 0 (XRD) \\
\hline
\end{tabular}

Table 5. Field Measurements and Methods

\begin{tabular}{lll}
\hline Measurement & Method & Procedure/Reference \\
\hline $\begin{array}{l}\text { Soil Matric } \\
\text { Potential }\end{array}$ & $\begin{array}{l}\text { Tensiometer/Heat } \\
\text { Dissipation Sensor }\end{array}$ & $\begin{array}{l}\text { Cassel and Klute (1986), Campbell } \\
\text { and Gee (1986) }\end{array}$ \\
$\begin{array}{l}\text { Soil Water } \\
\text { Content }\end{array}$ & Capacitance Probe & \\
Soil Temperature & Thermocouple & Taylor and Jackson (1986) \\
pH & & \\
EC & & \\
\hline
\end{tabular}




\subsection{Schedule}

Depending on the final cost for the production of the experimental glass, modification of one to three of the FLTF lysimeters will take place in FY02, including installation of sensors and samplers. It is anticipated that the small-sized experimental glass cylinders (46-cm high and 20-cm diameter) will be used. At least 3 years of in situ measurements in the lysimeters are anticipated. Excavation of one of the lysimeters containing HAN28F glass and analyses of the excavated samples will take place in FY06 before emplacement of actual ILAW glass in the first disposal facility trench. The remaining two lysimeters will continue to be monitored to provide a long-term data record of glass behavior. A schedule for excavation of these lysimeters will be based on the data record. 


\subsection{Environment, Safety, and Health}

As specified in the Environment, Safety, and Health (ES\&H) Requirements section of the Project Management Plan, all precautionary measures will be taken in accordance with standard PNNL safety procedures to ensure that laboratory and field work will be conducted in a safe manner. All staff performing laboratory or field work will have been trained in the appropriate ES\&H requirements. 


\subsection{Waste and Residuals Management}

PNNL will be responsible for managing waste and residuals. These activities will be accomplished following specific activities during modification of the FLTF lysimeters, operation of the experiments, and soil and solution sampling.

\subsection{Management Activity A - Solid Waste Management Plan for FLTF Lysimeter Modification}

Scope: This plan covers waste disposition for the waste generated from decommissioning of the current lysimeter experiment(s) and installation of the new ILAW experiments.

Anticipated Waste Streams: Based on this test plan, materials from decommissioning of the current FLTF lysimeter experiments will include various uncontaminated environmental media (silt loam, sand, and gravel sediments), which are not a regulated waste. Waste materials may include an asphaltic concrete material.

Waste Management: The asphaltic concrete material will be disposed of as construction material. Before the experiments begin, applicable permits will be procured.

Contingency Plan: In the event of a spill or an accidental release to the environment, the procedure for spill response (http://sbms.pnl.gov/standard/0e/0e00t010.htm) will be in effect.

If a spill occurs, call (509) 375-2400.

\subsection{Management Activity B - Solid Waste Management Plan for Operation of the Experiments}

Scope: This plan covers waste disposition for the waste generated from operation of the new lysimeter experiment(s).

Anticipated Waste Streams: Based on this test plan, waste materials from operation of the new FLTF lysimeter experiments may include drainage water from the lysimeters containing trace amounts of the experimental tracers.

Waste Management: It is anticipated that concentrations of chemicals (such as the tracers used in the glass) in the lysimeter drainage water will be below regulatory limits so that the drainage water can be disposed of to ground as is currently done with drainage from the existing lysimeters. Before the experiments begin, a Field Chemical 
Disposal/Recycle Request form will be completed and approved following the Managing Waste requirements in PNNL's Standards-Based Management System (SBMS) (http://sbms.pnl.gov/standard/0f/0f00t010.htm).

Contingency Plan: In the event of a spill or an accidental release to the environment, the procedure for spill response (http://sbms.pnl.gov/standard/0e/0e00t010.htm will be in effect.

If a spill occurs, call (509) 375-2400.

\subsection{Management Activity C - Solid Waste Management Plan for Soil and Solution Sampling}

Scope: This plan covers waste disposition for the waste generated from soil and solution sampling carried out as part of the new lysimeter experiments.

Anticipated Waste Streams: Based on this test plan, there are no anticipated waste streams to be generated from the soil and solution sampling. Soil and solution samples will be transported to PNNL facilities for analysis and will subsequently be disposed of according to PNNL waste management procedures.

If solid waste is generated, it is anticipated to be nonregulated, nonhazardous solid wastes, which may include paper, plastic, rags, etc.

Waste Management: The waste stream described above (paper, plastic, etc.) will be disposed of to a normal "trash" receptacle.

Contingency Plan: In the event of a spill or an accidental release to the environment, the procedure for spill response (http://sbms.pnl.gov/standard/0e/0e00t010.htm) will be in effect.

If a spill occurs, call (509) 375-2400. 


\subsection{Quality Assurance}

All work performed under this test plan will follow the applicable PNNL quality assurance (QA) requirements in PNNL's Standards-Based Management System (SBMS) and as specified in the QA section of the Project Management Plan. Details of tests performed and results will be documented in laboratory record books in accordance with the SBMS subject area Laboratory Record Books. Documentation will include identification of the technical procedures, materials, and calibrated measuring and test equipment (M\&TE) used, and the signature and date of the person who performed the work. M\&TE users will ensure that documentation of current calibration is maintained for M\&TE used. To meet the requirements of the Hanford Analytical Services Quality Assurance Requirements Document (HASQARD), analytical work will be conducted in accordance with PNNL's on-line QA plan, "Conducting Analytical Work in Support of Regulatory Programs." 


\subsection{References}

ASTM D 422-63. 1990. Method for Particle-Size Analysis of Soils, American Society for Testing and Materials, West Conshohoken, Pennsylvania..

Bacon, D. H. and B. P. McGrail. 2001. Waste Form Release Calculations for the 2001 Immobilized Low-Activity Waste Performance Assessment, PNNL-13369, Pacific Northwest National Laboratory, Richland, Washington.

Blake, G. R. and K. H. Hartge. 1986a. "Bulk Density." in Methods of Soil Analysis: Part 1 - Physical and Mineralogical Methods, Second Edition, A. Klute (ed.), pp.363-376, American Society of Agronomy, Inc., Madison, Wisconsin.

Blake, G. R. and K. H. Hartge. 1986b. "Particle Density." in Methods of Soil Analysis: Part 1 - Physical and Mineralogical Methods, Second Edition, A. Klute (ed.), pp.377382, American Society of Agronomy, Inc., Madison, Wisconsin.

Burbank, D. A., 2001. Conceptual Design Report for Immobilized Low-Activity Waste Disposal Facility Project W-520, RPP-7908, Rev. 0, CH2Mhill Hanford Group, Inc., Richland, Washington.

Campbell, G. S. and G. W. Gee. 1986. "Water Potential: Miscellaneous Methods." in Methods of Soil Analysis: Part 1 - Physical and Mineralogical Methods, Second Edition, A. Klute (ed.), pp.619-633, American Society of Agronomy, Inc., Madison, Wisconsin.

Cassel, D. K. and A. Klute. 1986. "Water Potential: Tensiometry." in Methods of Soil Analysis: Part 1 - Physical and Mineralogical Methods, Second Edition, A. Klute (ed.), pp.563-596, American Society of Agronomy, Inc., Madison, Wisconsin.

DOE/RL. 1999. 200-BP-1 Prototype Barrier Treatability Test Report, DOE/RL-99-11, Rev. 0, U.S. Department of Energy, Richland, Washington.

Fayer, M. J., E. M. Murphy, J. L. Downs, F. O. Khan, C. W. Lindenmeier, and B. N. Bjornstad.1999. Recharge Data Package for the Immobilized Low-Activity Waste 2001 Performance Assessment, PNNL-13033, Pacific Northwest National Laboratory, Richland, Washington.

Gee, G. W. and J. W. Bauder. 1986. "Particle-Size Analysis." in Methods of Soil Analysis: Part 1 - Physical and Mineralogical Methods, Second Edition, A. Klute (ed.), pp.383-412, American Society of Agronomy, Inc., Madison, Wisconsin. 
Janin, L. F. and R. K. Biyani. 2000. Closure Plan for the Immobilized Low-Activity Waste Disposal Facility (Draft), HNF-3281, Rev. C, COGEMA Engineering Corp., Richland, Washington.

Klute, A. 1986. "Water Retention: Laboratory Methods." in Methods of Soil Analysis: Part 1 - Physical and Mineralogical Methods, Second Edition, A. Klute (ed.), pp. 635662, American Society of Agronomy, Inc., Madison, Wisconsin.

Klute, A. and C. Dirksen. 1986. "Hydraulic Conductivity and Diffusivity: Laboratory Methods." in Methods of Soil Analysis: Part 1 - Physical and Mineralogical Methods, Second Edition, A. Klute (ed.), pp. 687-734, American Society of Agronomy, Inc., Madison, Wisconsin.

Larrick, A. P., S. G. Pitman, and J. R. Divine Jr. 1995. 9090 Test Results [PNL Final Report for Liner \& Process Condensate Compatibility Test in Support of W-150 LERF], WHC-SD-W105-TD-001, Westinghouse Hanford Company, Richland, Washington..

Mann, F.M. and R.J. Puigh II. 2000. Data Packages for the Hanford Immobilized LowActivity Tank Waste Performance Assessment: 2001 Version, HNF-5636, Fluor Federal Services, Richland, Washington.

Mann, F.M., R.J. Puigh II, S.H. Finfrock, E.J. Freeman, R. Khaleel, D.H. Bacon, M.P. Bergeron, B.P. McGrail, and S.K. Wurstner. 2001. Hanford Immobilized Low-Activity Waste Performance Assessment: 2001 Version, DOE/ORP-2000-24, Rev. 0, U.S. Department of Energy, Richland, Washington.

Mann, F.M., R.J. Puigh II, E.J. Freeman, S.H. Finfrock, D.H. Bacon, M.P. Bergeron, B.P. McGrail, and S.K. Wurstner. 2000. White Paper Updating Conclusions of 1998 ILAW Performance Assessment, DOE/ORP-2000-07, Rev. 0, U.S. Department of Energy, Richland, Washington, April.

Mann, F.M., R.J. Puigh II, P.D. Rittmann, N.W. Kline, J.A. Voogd, Y. Chen, C.R. Eiholzer, C.T. Kincaid, B.P. McGrail, A.H. Lu, G.F. Williamson, N.R. Brown, and L.E. LaMont. 1998. Hanford Immobilized Low-Activity Tank Waste Performance Assessment, DOE/RL-97-69, U.S. Department of Energy, Richland Operations Office, Richland, Washington.

McGrail, B.P., D.H. Bacon, J.P. Icenhower, W.L. Ebert, P.F. Martin, H.T. Schaef, and E.A. Rodriguez. 2001. Waste Form Release Data Package for the 2001 Immobilized Low-Activity Waste Performance Assessment, PNNL-13043, Rev. 2, Pacific Northwest National Laboratory, Richland, Washington, 
Meyer, P. D. and R. J. Serne. 1999. Near-Field Hydrology Data Package for the Immobilized Low-Activity Waste 2001 Performance Assessment, PNNL-13035, Pacific Northwest National Laboratory, Richland, Washington.

Saripalli, K. P., P. S. C. Rao, and M. D. Annable. 1998. "Determination of Specific NAPL-Water Interfacial Areas of Residual NAPLs in Porous Media Using the Interfacial Tracers Technique.” J. Contaminant Hydrology, 30(3):375-391.

Taylor, S. A. and R. D. Jackson. 1986. "Temperature." in Methods of Soil Analysis: Part 1 - Physical and Mineralogical Methods, Second Edition, A. Klute (ed.), pp.927-940, American Society of Agronomy, Inc., Madison, Wisconsin.

WHC. 1994. Construction Quality Assurance Report, WHC-SD-W025-RPT-001, Rev. 0, Westinghouse Hanford Company, Richland, Washington.

Whitlock, R. W., 1995. A Final Report for Lab Testing of Geomembrane for Waste Containment EPA Method 9090, WHC-SD-WM-TRP-237, Westinghouse Hanford Company, Richland, Washington.

Willard, H. H., L. L. Merritt, Jr., J. A. Dean, and F. A. Settle, Jr. 1988. Instrumental Methods of Analysis, Wadsworth Publishing Co., Belmont, California.

Wolery T.J. 1992. EQ3NR, A Computer Program for Geochemical Aqueous SpeciationSolubility Calculations: Theoretical Manual, User's Guide, and Related Documentation (Version 7.0), UCRL-MA-110662 PT III, Lawrence Livermore National Laboratory, Livermore, California. 


\section{Figures}




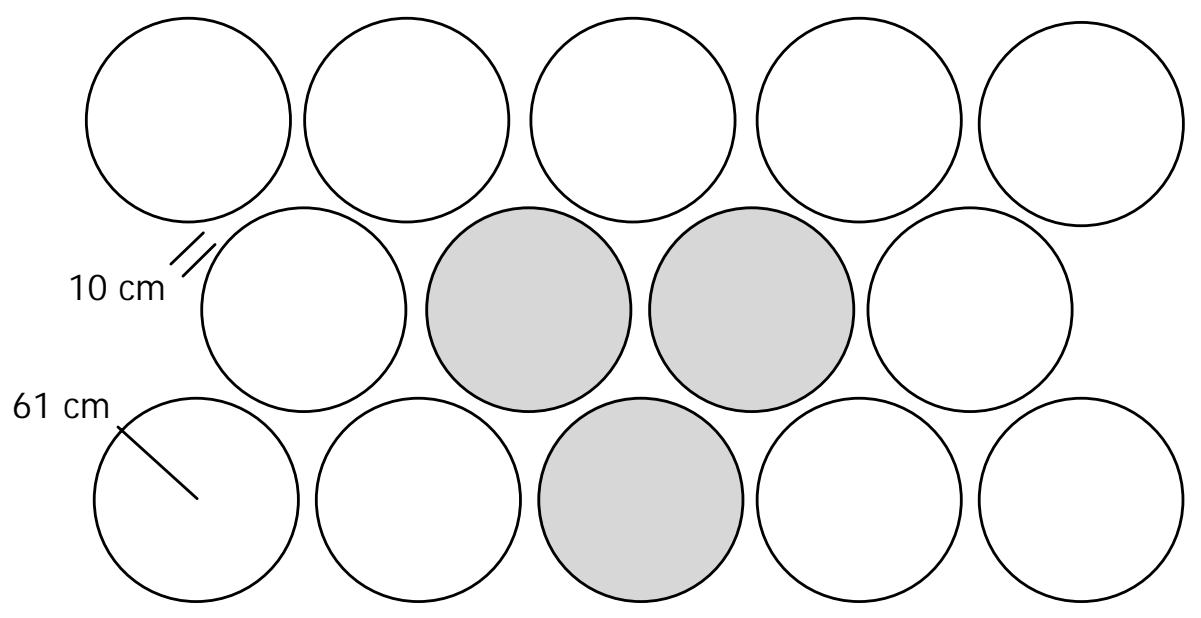

Figure 1. Plan View of Hexagonal Packing of Glass Cylinders in the Disposal Facility With a Representation of the Experimental Subunit. 

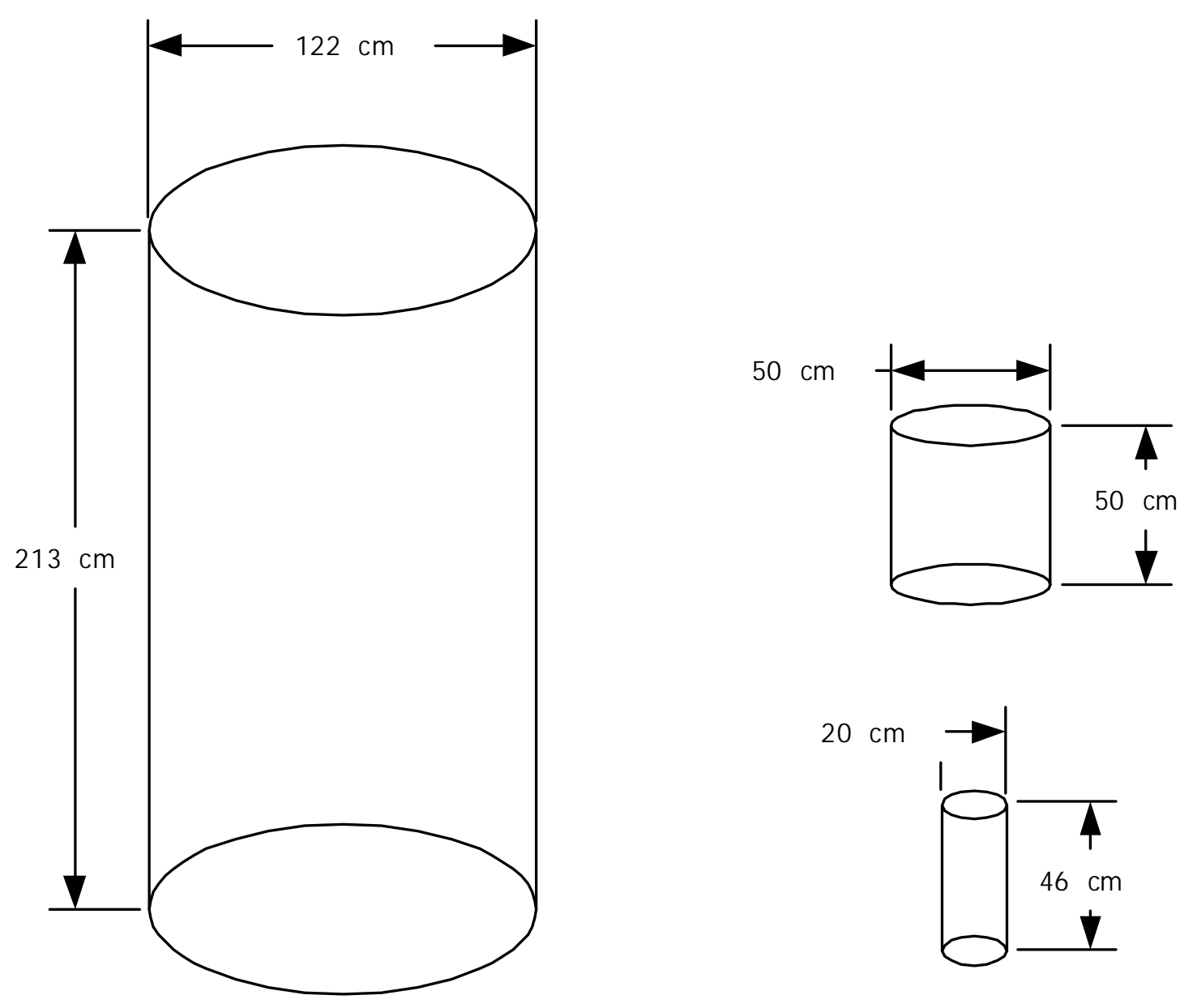

Figure 2. Relative Size of Proposed Experimental Glass Blocks (Right) Compared to the Full-Size Blocks of the ILAW Disposal Facility (Left). 

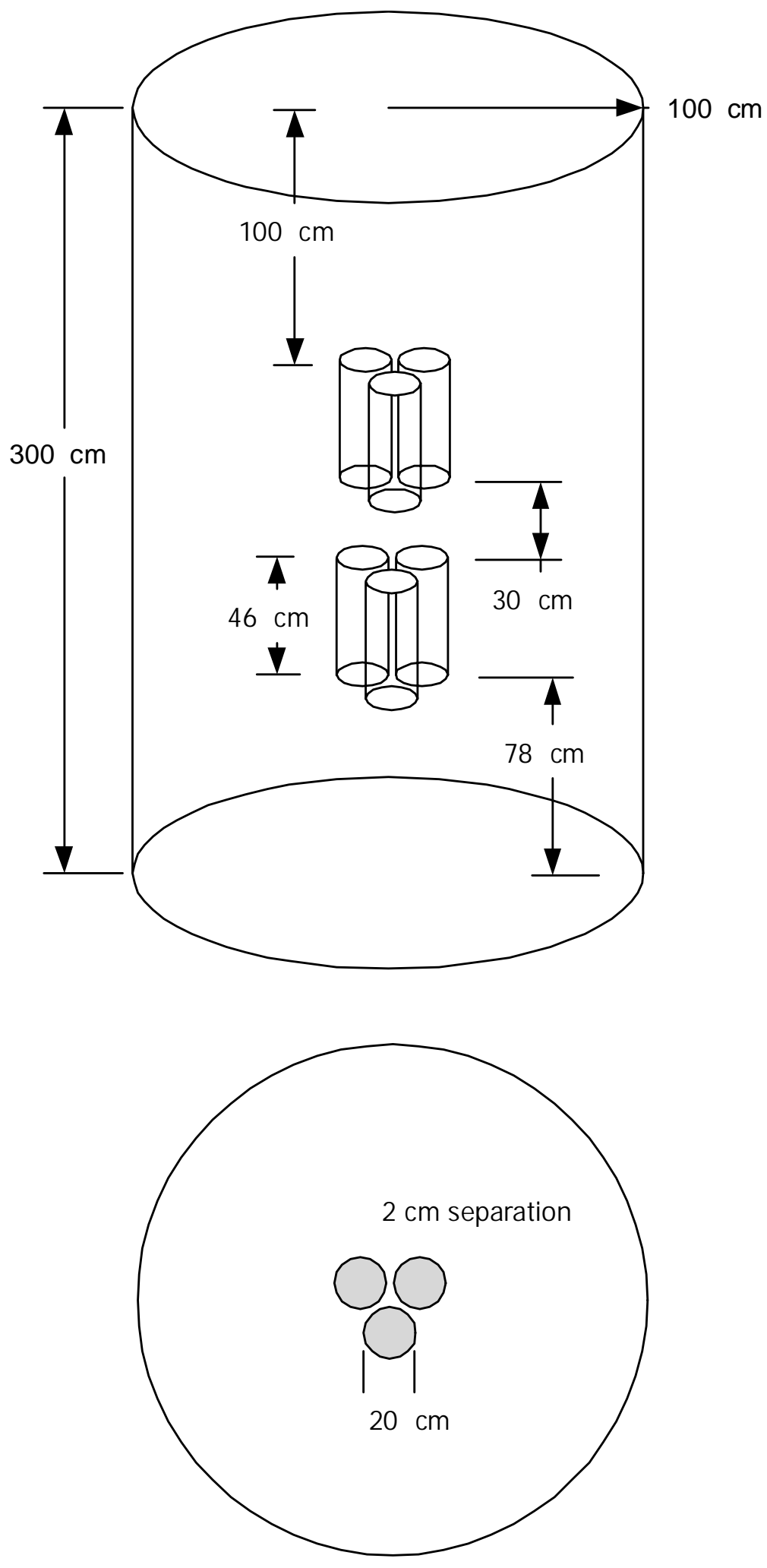

Figure 3. Configuration of Experimental Glass Cylinders Within a Lysimeter. 


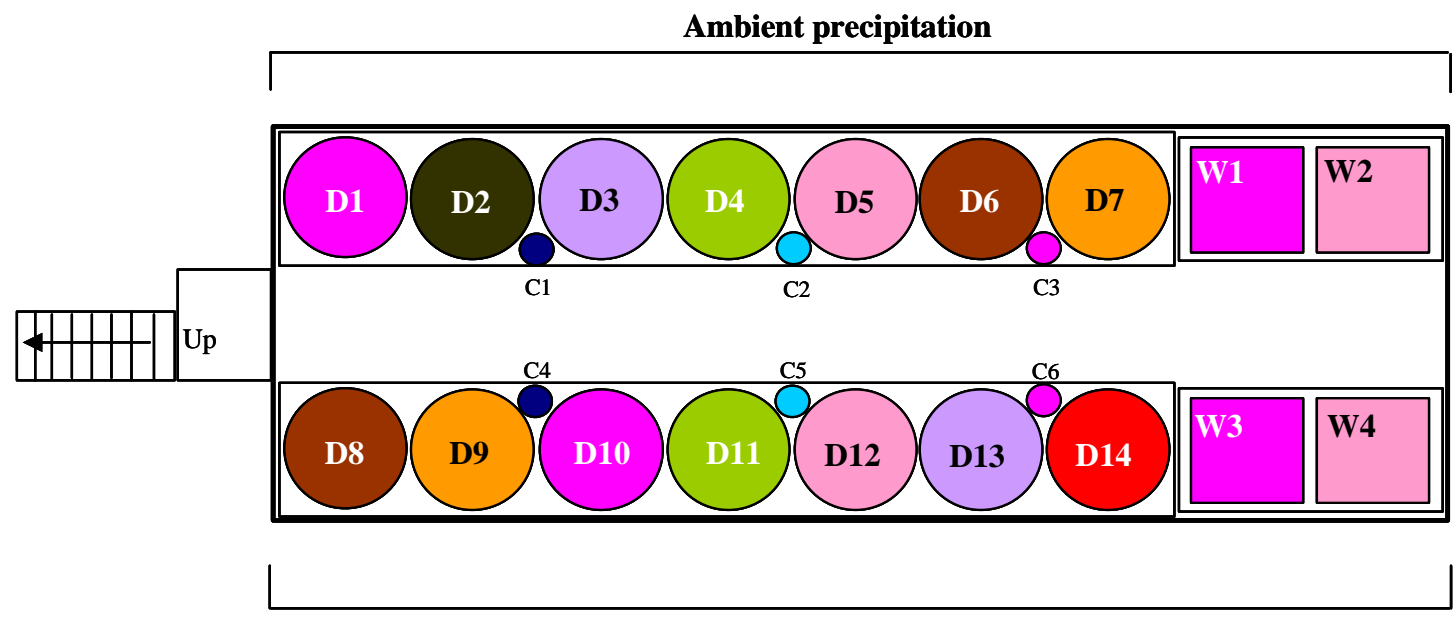

Enhanced precipitation

\begin{tabular}{|l|l|l|l|l|}
\hline Hanford Barrier & Gravel Mulch & Basalt Sideslope & $\begin{array}{l}\text { Hanford } \\
\text { Prototype Barrier }\end{array}$ & $\begin{array}{l}\text { Sand Dune } \\
\text { Migration }\end{array}$ \\
\hline \begin{tabular}{l|l|l|} 
Eroded Hanford \\
Barrier
\end{tabular} & Pitrun Sand & $\begin{array}{l}\text { Sandy Gravel } \\
\text { Sideslope }\end{array}$ & $\begin{array}{l}\text { Hanford Barrier } \\
\text { w/Dune Sand }\end{array}$ & $\begin{array}{l}\text { Modified RCRA } \\
\text { Subtitle C Cover }\end{array}$ \\
\hline
\end{tabular}

Figure 4. Plan View of the FLTF Showing the Current Experiments. 

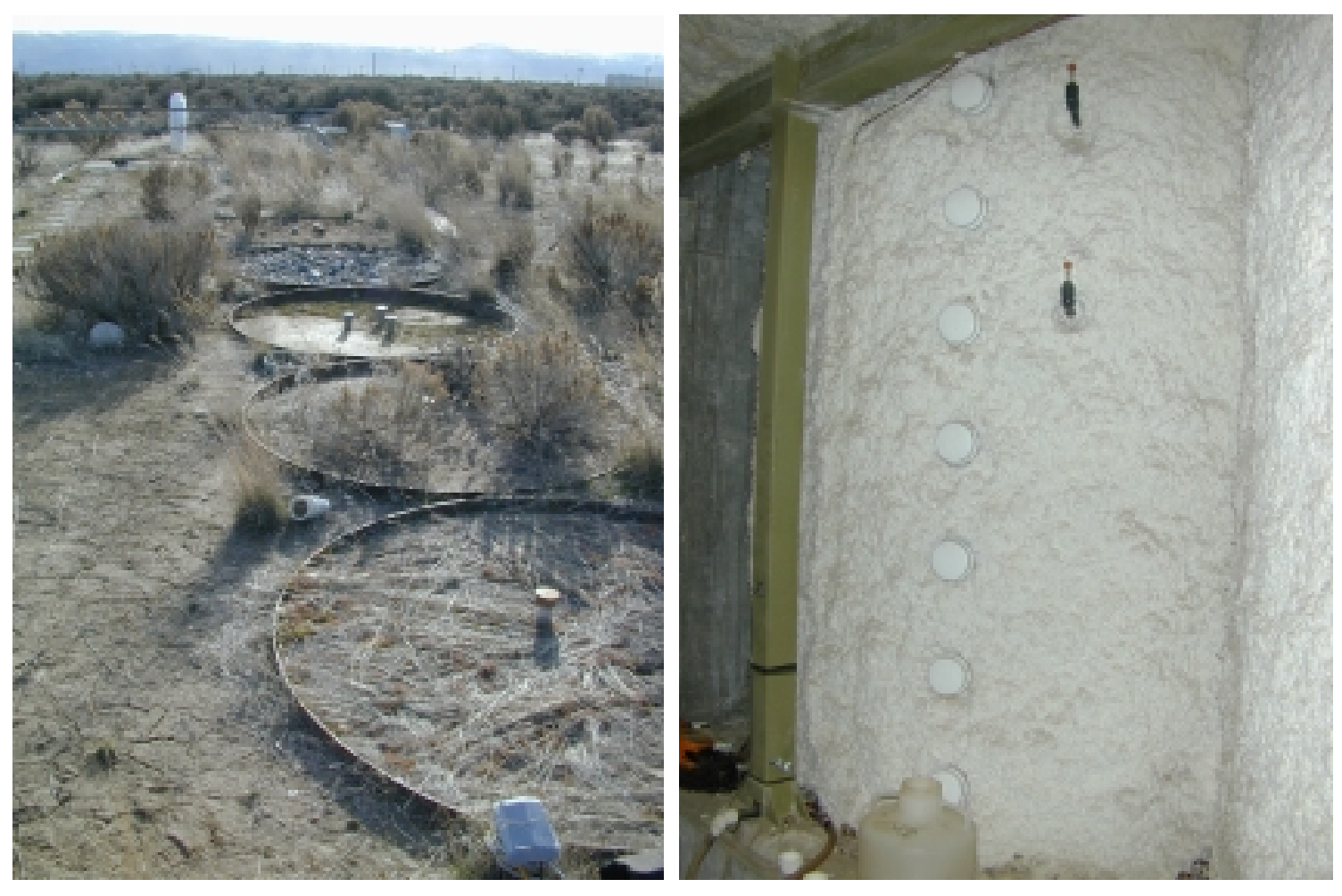

Figure 5. Surface of FLTF (Left) Showing Several Lysimeters and a View from the Underground Vault (Right) showing the Side of a Lysimeter with Instrument Access Ports. 

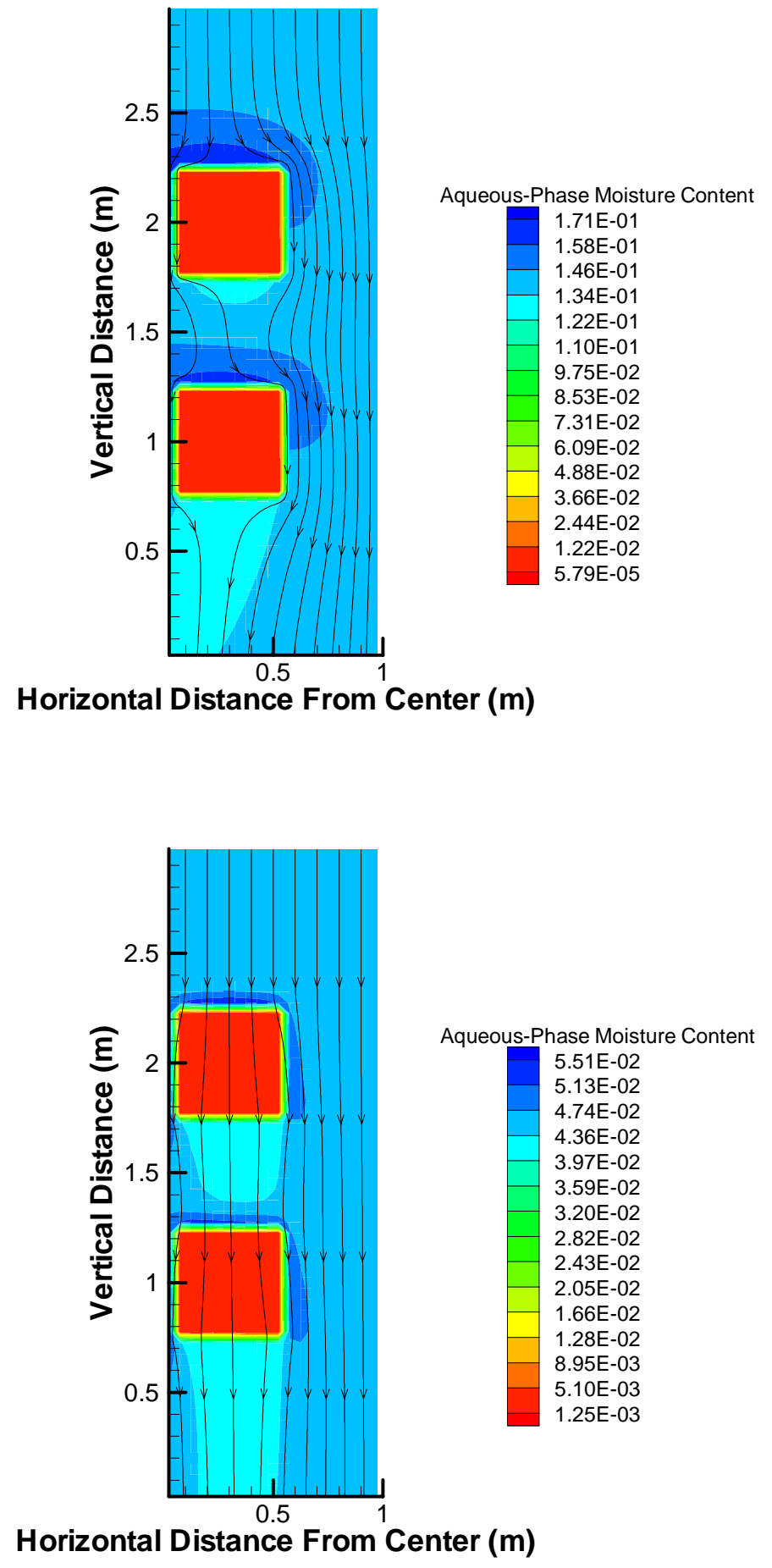

Figure 6. Steady-State Volumetric Water Content for the Lysimeter Simulation with an Applied Water Flux Of 200 mm/yr and the Fine (Top) and Coarse (Bottom) Backfill Properties. 

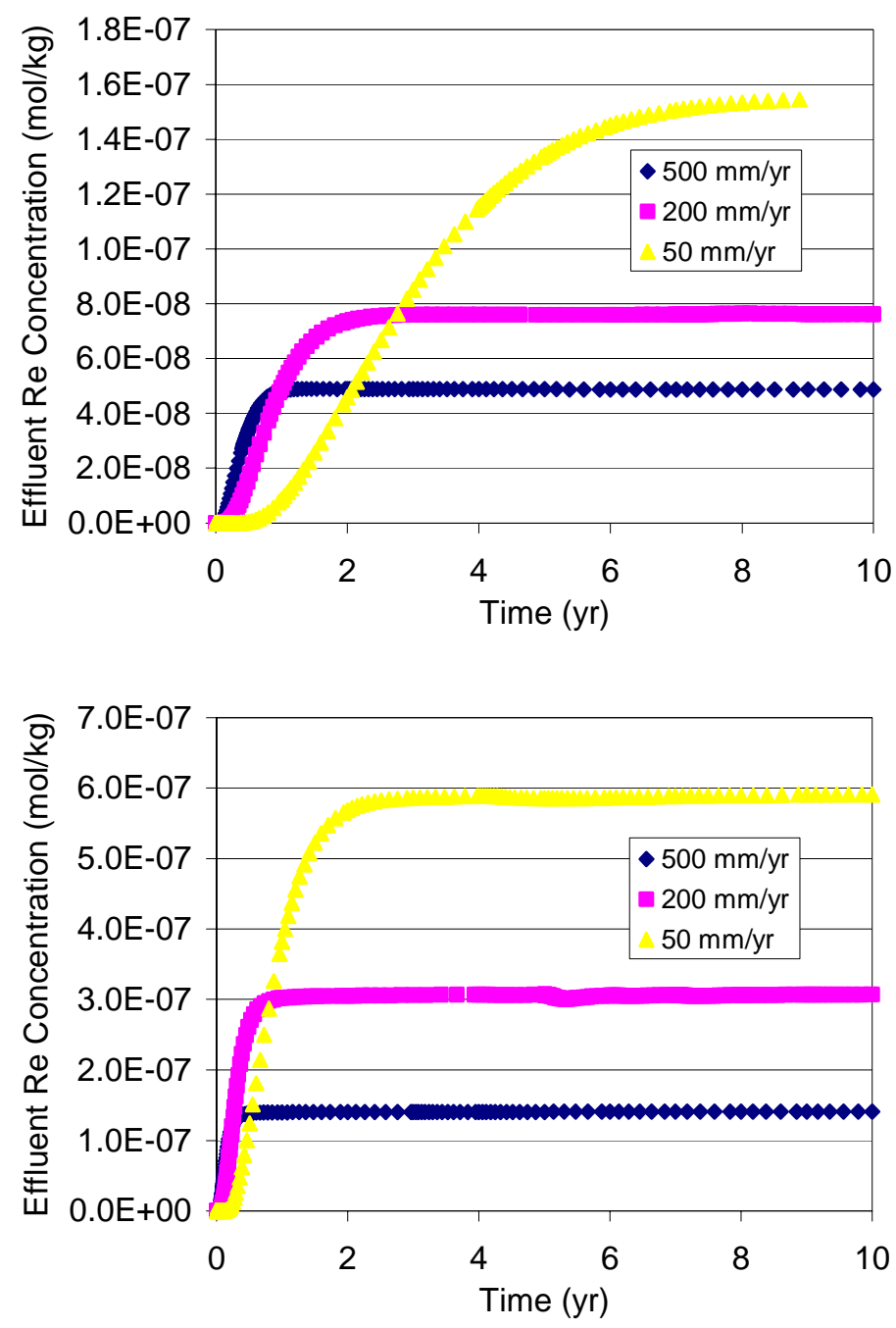

Figure 7. Simulated Rhenium Tracer Concentration in the Lysimeter Drainage for Three Applied Water Fluxes: Fine Backfill Properties (Top) and Coarse Backfill Properties (Bottom). 

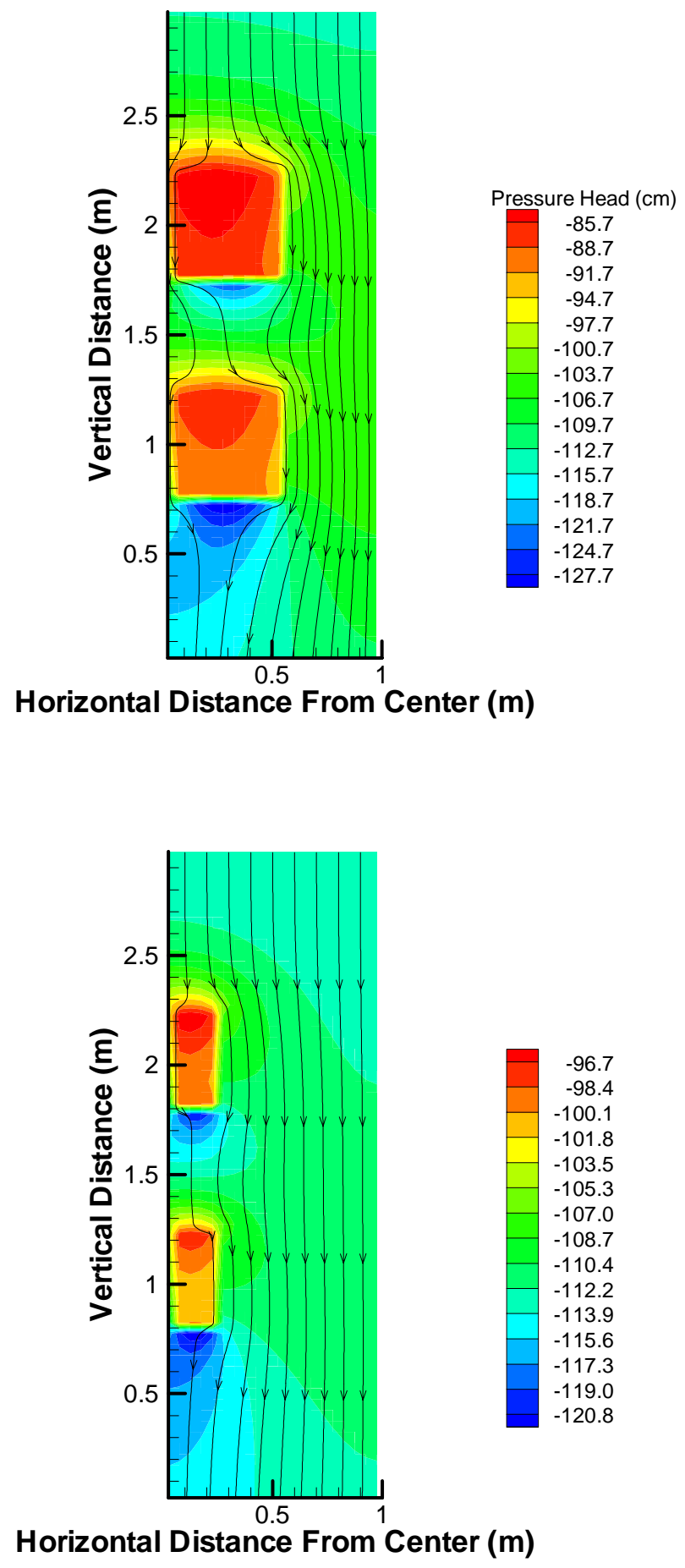

Figure 8. Steady-State Pressure Head for the Lysimeter Simulation with the 50-cm (Top) and 20-cm (Bottom) Diameter Glass Cylinders Using an Applied Water Flux Of $200 \mathrm{~mm} / \mathrm{yr}$ and the Fine Backfill Properties. 


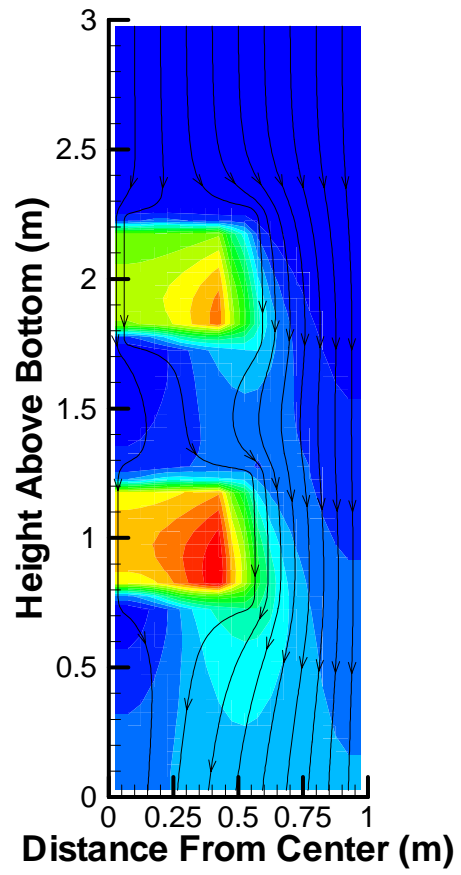

$$
\begin{aligned}
& \text { Fine Backfill } \\
& 10 \mathrm{yr} \\
& 200 \mathrm{~mm} / \mathrm{yr}
\end{aligned}
$$

$3.43 \mathrm{E}-07$

3.19E-07

2.94E-07

2.70E-07

2.45E-07

2.21E-07

1.96E-07

1.72E-07

1.47E-07

$1.23 \mathrm{E}-07$

9.80E-08

7.35E-08

4.90E-08

2.45E-08

\section{Distance From Center (m)}

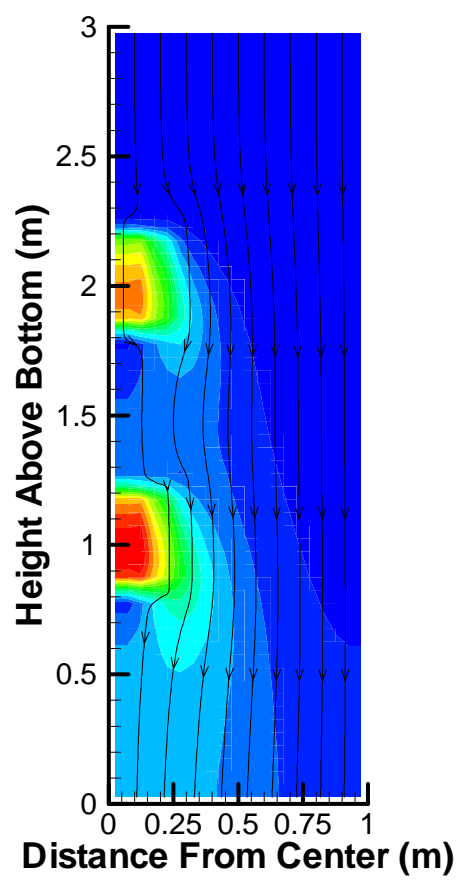

Fine Backfil

$10 \mathrm{yr}$

$200 \mathrm{~mm} / \mathrm{yr}$

$\mathrm{ReO} 4-(\mathrm{mol} / \mathrm{kg})$

4.02E-07

3.75E-07

3.48E-07

3.22E-07

2.95E-07

2.68E-07

2.41E-07

2.14E-07

1.88E-07

$1.61 \mathrm{E}-07$

1.34E-07

1.07E-07

8.04E-08

5.36E-08

2.68E-08

Figure 9. Rhenium Concentrations After 10 Years of Dissolution with the 50-cm (Top) and 20-cm (Bottom) Diameter Glass Cylinders Using an Applied Water Flux of $200 \mathrm{~mm} / \mathrm{yr}$ and the Fine Backfill Properties. 


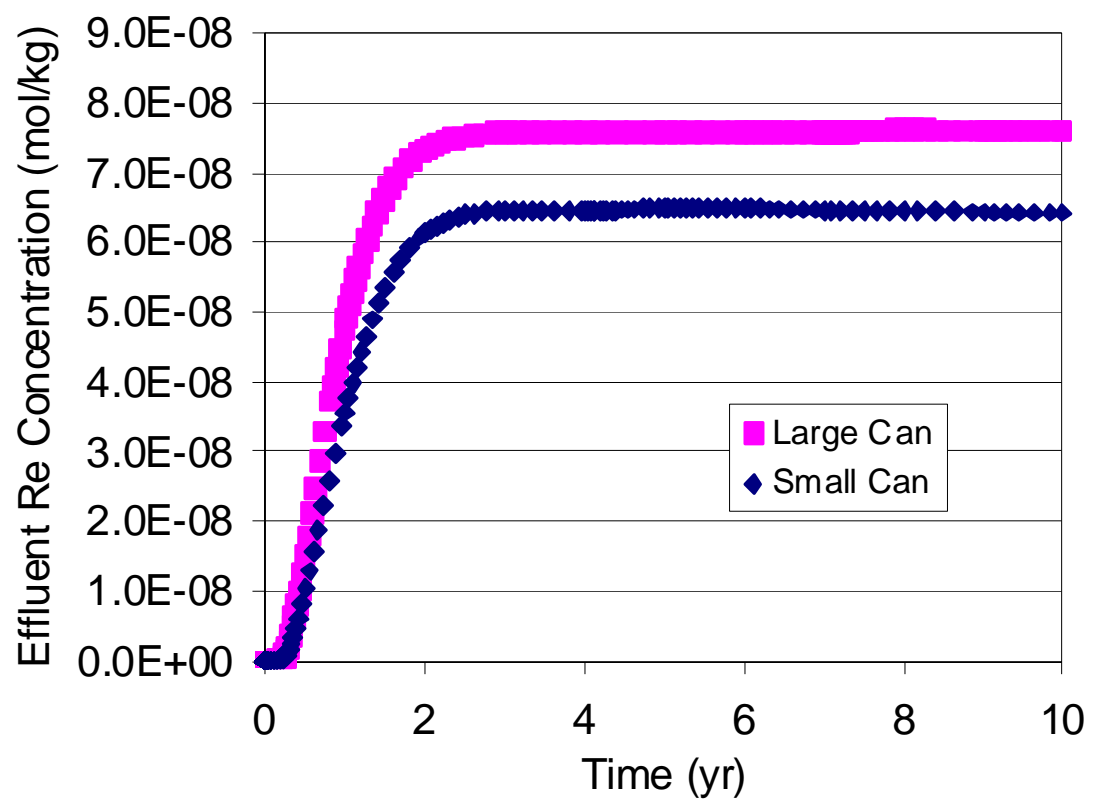

Figure 10. Simulated Rhenium Tracer Concentration in the Lysimeter Drainage for the 50-cm (Large Can) and 20-cm (Small Can) Diameter Glass Cylinders Using an Applied Water Flux of $200 \mathrm{~mm} / \mathrm{yr}$ and the Fine Backfill Properties. 


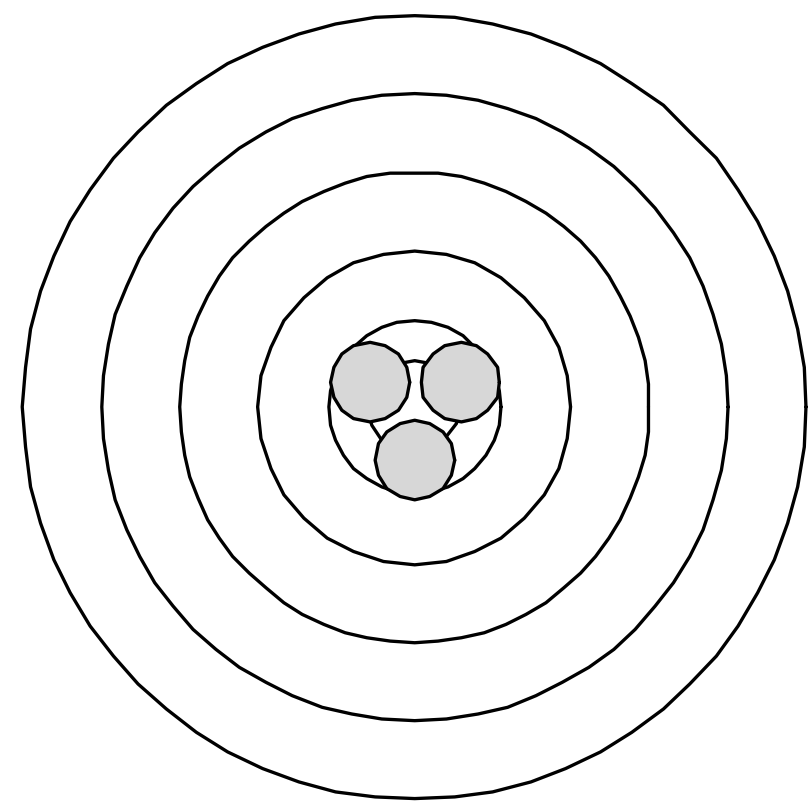

\begin{tabular}{|c|c|c|c|}
\hline Radius (cm) & Area Sampled $\left(\mathrm{cm}^{\wedge} 2\right)$ & $\%$ Total Area & Drainage (cc/wk) \\
\hline 12 & 452.4 & 1.4 & 174.0 \\
\hline 22 & 1068.1 & 3.4 & 410.8 \\
\hline 40 & 3506.0 & 11.2 & 1348.5 \\
\hline 60 & 6283.2 & 20.0 & 2416.6 \\
\hline 80 & 8796.5 & 28.0 & 3383.3 \\
\hline 100 & 11309.7 & 36.0 & 4349.9 \\
\hline
\end{tabular}

Estimated Drainage Rate $=$

$200 \mathrm{~mm} / \mathrm{yr}$

Figure 11. Arrangement of the Passive Capillary Wick Collection Pans on the Bottom of the Lysimeters. Shaded Areas Indicate the Location of the Glass Cylinders Above the Collection Pans. The Table Provides the Radius of Pans, Areas Sampled, and Estimated Drainage in Each Pan 


\section{Distribution}

No. of

Copies

ONSITE

DOE Richland Operations Office

C. A. Babel

H6-60

N. R. Brown

H6-60

P. E. Lamont

H6-60

Public Reading Room

$\mathrm{H} 2-53$

Bechtel Hanford, Inc.

G. A. Jewell

H0-21

B. H. Ford

H0-19

A. J. Knapp

$\mathrm{H} 0-22$

Lockheed Martin Hanford Corp

J. A. Voogd

H6-64
No. of

Copies

ONSITE

Pacific Northwest National Laboratory

D. H. Bacon

K9-33

R. W. Bryce

K6-75

M. J. Fayer

K9-33

E. J. Freeman

K9-33

G. W. Gee

K9-33

C. T. Kincaid

K9-33

C. W. Lindenmeier

K6-81

B. P. McGrail

P. D. Meyer (5)

S. P. Reidel

K. P. Saripalli

R. J. Serne

A. L. Ward
K6-81

BPO

K6-81

K6-81

K6-81

K9-33

\section{CH2 M Hill Hanford Group}

D. A. Burbank

K. C. Burgard

T. A. Carlson

S. H. Finfrock

F. M. Mann (2)

R. J. Puigh

R. W. Root
S4-45

S4-45

B4-09

B4-43

H0-22

B4-43

R2-53 